\title{
ANALISIS RELIABILITY AVAILABILITY DAN MAINTAINABILITY PADA GANTRY JIB CRANE DI PELABUHAN
}

\author{
Norman Iskandar*, Sulardjaka, Yoga Pangestu Soebroto \\ Departemen Teknik Mesin, Fakultas Teknik, Universitas Diponegoro \\ Jl. Prof. Sudharto, Tembalang, Semarang 50275. \\ "Email: norman.undip@gmail.com
}

\begin{abstract}
Abstrak
Gantry Jib Crane (GJC) merupakan salah satu jenis mesin pesawat angkat angkut yang memiliki peran vital dalam layanan bongkar muat di pelabuhan. Pada salah satu lokasi di PT Pelabuhan Indonesia mengalami masalah pada prosedur perawatan GJC, sehingga berakibat kegiatan bongkar muat barang dan pelayanan gudang tidak dapat berjalan dengan baik dan lancar sesuai jadwal. Tujuan dari penelitian ini adalah untuk menganalisis data perawatan dan kerusakan yang selama ini diterapkan dan terjadi dilapangan, serta mengukur tingkat ketersediaan atau availability dari beberapa Gantry Jib Crane yang ada di pelabuhan sebagai sebuah langkah continuous improvement. Metode yang digunakan adalah perhitungan mean to time repair (MTTR), mean time between failure (MTBF) dan availability dan reliability. Dari hasil kajian diperoleh kesimpulan bahwa dari empat GJC yang ada ada dua unit GJC yaitu GJC 02 dan GJC 03 yang tingkat availabilitynya lebih rendah dari dua GJC yang lain. Dari hasil analisis juga diberikan rekomendasi terkait besaran jam interval predictive maintenance yang baru, untuk kedua GJC tersebut.
\end{abstract}

Kata kunci: Availability, gantry jib crane, preventive maintenance, reliability

\section{PENDAHULUAN}

Perkembangan industri di dunia semakin pesat terutama di bidang jasa ke pelabuhan yang menyediakan jasa bongkar muat curah maupun peti kemas, sebagian besar pergerakan pengiriman barang banyak sekali negara negara berkembang menggunakan jasa pelabuhan untuk melakukan bongkar muat, tak terkecuali di Indonesia. Dimana Indonesia adalah negara kepulauan yang mayoritas pengiriman barang jauh lebih mudah menggunakan jalur laut. PT. Pelabuhan Indonesia (Persero) adalah pihak yang menguasai dan mengurusi lalu lintas dan bongkar muat barang di Indonesia.

Gantry Jib Crane (GJC) merupakan pesawat angkat angkut yang digunakan sebagai alat bongkar muat dari kapal ke dermaga atau sebaliknya, bahkan merupakan salah satu sistem alat bongkar muat utama dan sangat penting keberadaannya dalam menunjang kinerja dari PT. Pelabuhan Indonesia (Persero). GJC bisa dikatakan merupakan urat nadi aktivitas perusahaan dalam proses bongkar muat barang dari kapal ke dermaga atau sebaliknya.

Aktivitas yang tinggi menuntut alat harus senantiasa siap. Kesiapan alat akan berkaitan langsung dengan kelancaran proses kerja, safety atau keamanan dan keselamatan kerja, lingkungan serta berkorelasi terhadap finansial.

Kesiapan alat yang baik menuntut sistem perawatan yang baik efektif dan efisien dan berbiaya rendah. Hal ini karena aktivitas perawatan merupakan kegiatan pendukung bagi tujuan utama yaitu tujuan komersial (Hardianto dkk., 2015) dan (Mokashi dkk., 2002). Pemeliharaan juga mempengaruhi keandalan dan dengan demikian dapat memiliki konsekuensi lingkungan dan keselamatan (Mokashi dkk., 2002).

Perawatan dan pemeliharaan pada GJC diperlukan agar pengoperasian sistem berjalan lancar, sehingga aktivitas bongkar muat barang baik dari dalam kapal maupun dari luar kapal dapat memenuhi target kerja atau waktu yang telah ditentukan. Sistem atau alat yang bergerak dan beroperasi terus setiap hari membutuhkan pemeliharaan dan perawatan yang teratur agar operasionalnya berjalan dengan lancar dan usia pakai alat sesuai dengan rekomendasi perusahaan pembuatnya (CIAB, 2010). Beberapa aktivitas perawatan rutin yang dilakukan pada GJC adalah pergantian oil engine, oil filter, fuel filter, coolant filter dan 
air filter setiap 250 jam, pergantian wire rope yang dilakukan pada saat tali kawat baja putus 3 helai sesuai aturan dan panduan dalam standar perawatan yang direkomendasikan, atau terbentuknya sudut $7 \%$ dari posisi awal, serta melakukan gressing pada komponenkomponen alat yang ada pada GJC.

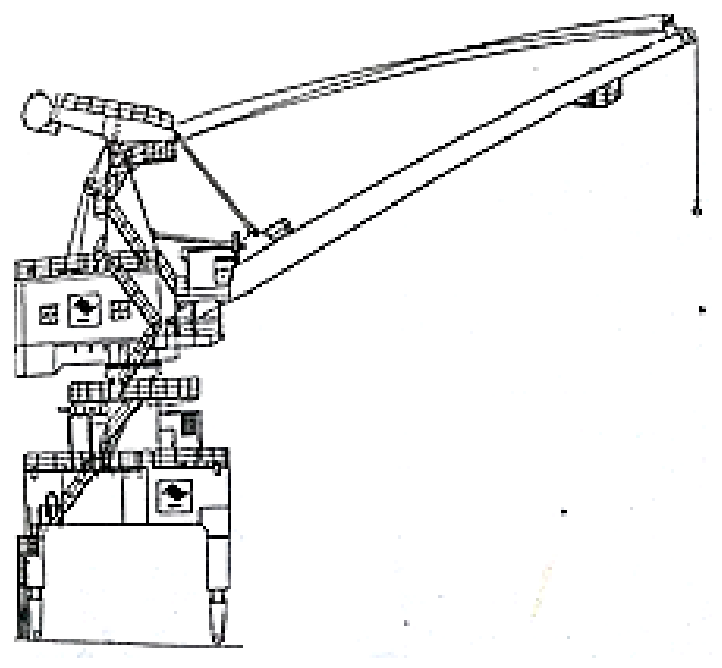

\section{Gambar 1. Gantry Jib Crane (GJC)}

Meskipun sudah mencoba menerapkan preventif maintenance $(\mathrm{PM})$ secara teratur dan sebaik mungkin, kondisi GJC di lapangan kadang kala masih dirasakan ada permasalahan terkait ketersediaan alat untuk beroperasi. Kendala ketersediaan alat ini mengganggu jadwal bongkar muat yang sudah dirancang.

Dugaan yang muncul adalah masih adanya kondisi kurang optimal dari mekanisme perawatan yang selama ini dijalankan, sehingga penelitian ini mencoba menganalisis dan melakukan proses pengecekan terhadap proses perawatan yang selama ini sudah berjalan, sehingga bisa memberikan koreksi terhadap sistem perawatan sebagai sebuah langkah continuous improvement atau perbaikan secara terus menerus. Kajian terhadap keandalan (reliability), ketersediaan (availability), Mean Time To Repair (MTTR), Mean Time Between Failure (MTBF) terhadap GJC akan dijadikan topik bahasan utama dalam laporan ini.

Analisis Reliability, Availability dan Maintainability (RAM Analysis) dan memunculkan kemungkinan strategi perawatan/pemeliharaan yang dapat dimanfaatkan oleh pihak yang bertanggung jawab terhadap alat/mesin/sistem/pabrik untuk meningkatkan efektivitasnya (Hogan dkk., 2011). Dalam kurun waktu empat dekade terakhir, analisis keandalan telah menjadi standar utama yang ditetapkan untuk digunakan sebagai instrumen atau alat yang terbukti bagus untuk melakukan analisis risiko, studi ketersediaan produksi dan desain sistem (Oystein, 1948) (Hauptmann dkk., 2009) (Tsarouhas, 2007).

Reliability dapat didefinisikan secara sederhana sebagai "probabilitas keberhasilan operasi". Probabilitas ini secara sederhana merupakan rasio jumlah komponen yang lulus uji kegagalan terhadap jumlah komponen yang ada ketika pengujian dimulai (Stapelberg, 2009). Reliability dapat dianalisis dengan dua cara, yaitu kuantitatif dan kualitatif. Analisis kuantitatif dilakukan jika tersedia data yang mencukupi, sedangkan analisis kualitatif dilakukan ketika tidak tersedia data yang memadai, dimana diperlukan konsep kualitatif seperti ketidakpastian (uncertainty) dan tidak lengkapan (incompleteness) (Stapelberg, 2009).

Metode kualitatif yang sering digunakan adalah Failure Modes And Effects Analysis (FMEA), sedangkan metode kuantitatif yang sering digunakan adalah fault tree analysis, Reliability Block Diagram, dan Markov Analysis.

Berdasarkan pendekatannya, reliability terbagi atas pendekatan analitis dan pendekatan simulasi. Pendekatan analitik dapat dilakukan dengan menggunakan model matematis untuk melakukan penilaian indeks keandalan sistem, sedangkan pada pendekatan simulasi dapat dilakukan dengan cara menyimulasikan proses aktual dan perilaku acak (random behaviour), salah satunya dengan menggunakan simulasi Monte Carlo (Wu dkk., 2007).

Availability didefinisikan sebagai "probabilitas sebuah sistem bisa beroperasi dengan memuaskan pada setiap titik waktu, ketika digunakan dalam kondisi operasi yang ditentukan, dimana waktu yang dipertimbangkan termasuk waktu operasional dan waktu perbaikan aktif'. Nilai Availability inheren dapat dinyatakan dalam sebuah persamaan, seperti disajikan pada Persamaan 1 (Stapelberg, 2009). 


$$
\begin{aligned}
\text { Availability } & =\frac{\text { Up Time }}{\text { Total Time }} \\
\text { Availability } & =\frac{\text { Up Time }}{\text { Up Time }+ \text { Down Time }}
\end{aligned}
$$

Up Time adalah lama waktu sistem beroperasi dan Down Time adalah lama waktu sistem tidak beroperasi. Up Time berhubungan dengan nilai Mean Time Between Failure (MTBF) yang didefinisikan sebagai waktu rata-rata di antara dua kegagalan pada suatu sistem. Down Time berhubungan dengan nilai Mean Time To Repair (MTTR) yang merupakan nilai rata-rata waktu yang dibutuhkan untuk perbaikan suatu sistem. Rumus perhitungan MTBF dan MTTR dapat dilihat pada Persamaan 2 dan Persamaan 3.

$$
\begin{aligned}
& \text { MTBF }=\frac{\Sigma \text { Up time }}{\Sigma \text { kegagalan }} \\
& M T T R=\frac{\Sigma \text { Down time }}{\Sigma \text { kegagalan }}
\end{aligned}
$$

Sifat kegagalan dari suatu komponen dapat digambarkan menggunakan distribusi statistic (Shanaz dkk., 2012). Ada dua jenis distribusi data, yaitu diskret dan kontinyu. Distribusi diskret contohnya binomial, Poisson, geometrik, dan hipergeometrik, sedangkan contoh distribusi kontinyu yaitu normal, log normal, eksponensial, Weibull, gamma, dan beta.

Distribusi Weibull bentuk generalisasi dari distribusi eksponensial. Distribusi Weibull banyak digunakan karena memiliki kelebihan mampu memodelkan berbagai macam data dengan kriteria parameter bentuk (Kececioglu,1991). Fungsi kepadatan probabilitas tiga parameter Weibull dapat dinyatakan seperti dalam persamaan 4 .

$$
f(t)=\frac{\beta(t-\gamma)^{\beta-1}}{\theta^{\beta}} \exp \left(\frac{t-\gamma}{\theta}\right)^{\beta-1}
$$

Dimana :

$\beta=$ Parameter bentuk

$\theta \quad=$ Parameter skala

$\gamma \quad=$ Parameter lokasi

$\mathrm{t} \quad=$ Waktu (jam)

Distribusi Weibull 2 parameter merupakan distribusi Weibull dengan $\gamma=0$. Untuk $\mathrm{t} \geq \gamma$, fungsi keandalannya (reliability) adalah seperti dalam Persamaan 5.

$$
R(t)=\exp \left(-\left(\frac{t-\gamma}{\theta}\right)^{\beta}\right)
$$

\section{METODOLOGI}

Kinerja atau performa atau unjuk kerja suatu sistem/mesin /alat bergantung pada faktor reliability, availability, jenis peralatan yang digunakan, proses operasi yang dipilih serta keahlian operator dalam mengoperasikannya (Rosihan \& Yuniarto, 2019). Kondisi sistem/mesin/alat yang reliability dan availability rendah, pasti akan berkorelasi lurus dan sebanding dengan unjuk kerja atau performa yang rendah juga. Untuk meningkatkan performa/unjuk kerja maka perlu meningkatkan nilai reliability dan availability, dimana hal ini dapat dilakukan dengan cara menurunkan nilai kegagalan dan atau dengan meningkatkan efektivitas kegiatan perawatan dan perbaikan.

Penelitian dilakukan dengan menggunakan data yang diperoleh dari perusahaan dan observasi di lapangan secara langsung. Analisis availability dan reliability pada GJC dilakukan dengan menggunakan model distribusi probabilitas Weibull 3 parameter. Data hasil penghitungan akan dianalisis dan digunakan untuk acuan dalam memprediksi kapan sebaiknya perawatan sehingga GJC tetap dapat beroperasi secara optimal.

\section{HASIL DAN PEMBAHASAN \\ Availability, MTTR, MTBF pada Gantry Jib Crane (GJC)}

Tabel 1 menampilkan data tentang availability dari alat bongkar muat GJC sejumlah empat buah yang beroperasi di Pelabuhan pada bulan Januari-Juli yang diperoleh dari perusahaan. Dari data Tabel 1, terlihat data availability GJC 02 dan GJC 03 memiliki nilai terendah dari keempat GJC. Sehingga untuk analisis selanjutnya akan dipilih GJC 02 dan GJC 03 sebagai obyek kajian.

Tahapan selanjutnya adalah mendapatkan data (jam) nilai time to failure 
dan time to repair dari GJC 02 dan GJC 03. Setelah didapat data waktu antar kerusakan dan waktu perbaikan, data tersebut kemudian digunakan untuk menghitung nilai parameterparameter Weibull seperti mencari parameter bentuk $\beta$, parameter skala $\theta$, dan parameter lokasi $\gamma$ dari model yang didapat. Setelah dilakukan proses fitting menggunakan software Minitab 17, didapat parameterparameter $\beta, \theta, \gamma$ seperti yang disajikan pada Tabel 2.

Tabel 1. Data availability dari Gantry Jib Crane (GJC) bulan Januari-Juli

\begin{tabular}{|c|c|c|c|c|c|}
\hline \multirow{2}{*}{\multicolumn{2}{|c|}{$\begin{array}{c}\text { Ketersediaan } \\
\text { Gantry Jib } \\
\text { Crane }\end{array}$}} & \multicolumn{4}{|c|}{ Gantry Jib Crane No. } \\
\hline & & 01 & 02 & 03 & 04 \\
\hline \multirow{7}{*}{ 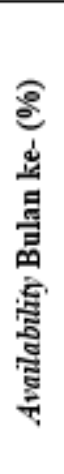 } & Januari & 99,76 & 100,00 & 99,40 & 99,67 \\
\hline & Februari & 99,16 & 98,31 & 99,23 & 98,46 \\
\hline & Maret & 98,13 & 97,45 & 97,28 & 97,92 \\
\hline & April & 99,46 & 99,27 & 99,35 & 99,39 \\
\hline & Mei & 99,72 & 99,17 & 97,54 & 98,65 \\
\hline & Juni & 99,81 & 97,93 & 99,08 & 99,54 \\
\hline & Juli & 99,76 & 99,76 & 99,60 & 99,60 \\
\hline \multicolumn{2}{|c|}{ Rata-rata (\%) } & 99,39 & 98,84 & 98,78 & 99,03 \\
\hline
\end{tabular}

Tabel 2. Perhitungan parameter-parameter Weibull menggunakan Minitab 17

\begin{tabular}{|c|c|c|}
\hline \multirow{2}{*}{$\begin{array}{c}\text { Parameter } \\
\text { Weibull } \\
\text { (Minitab 17) }\end{array}$} & \multicolumn{2}{|c|}{ Gantry Jib Crane No. } \\
\hline & $\mathbf{0 2}$ & $\mathbf{0 3}$ \\
\hline \multirow{3}{*}{ 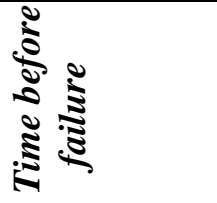 } & 1,0641 & 1,0839 \\
\hline & 77,8667 & 109,8428 \\
\hline & 32,8666 & 28,0971 \\
\hline \multirow{3}{*}{ 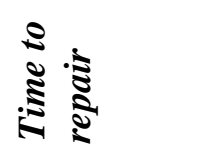 } & 0,6160 & 0,6628 \\
\hline & 0,8453 & 0,9243 \\
\hline & 0,1991 & 0,1983 \\
\hline
\end{tabular}

Selanjutnya dilakukan proses perhitungan nilai dari Mean Time Before Failure, Mean Time To Repair, dan Availability Komponen. Perhitungan Mean Time Before Failure (MTBF) dan Mean Time To Repair (MTTR) dilakukan menggunakan
Persamaan 6.

$$
M T B F=M T T R=\gamma+\theta \Gamma\left(\frac{1}{\beta}+1\right)
$$

Dimana

$$
\begin{array}{lll}
\beta & =\text { Parameter bentuk } \\
\theta & & =\text { Parameter skala } \\
\gamma & & \text { Parameter lokasi } \\
\mathrm{t} & =\text { Waktu (jam) } \\
\Gamma\left(\frac{1}{\beta}+1\right) & =\text { Fungsi gamma dari }\left(\frac{1}{\beta}+1\right)
\end{array}
$$

Persamaan yang digunakan untuk perhitungan MTBF dan MTTR sama, namun perhitungan MTBF menggunakan parameterparameter dari data antar kerusakan, sedangkan perhitungan MTTR menggunakan parameterparameter dari data waktu perbaikan. Persamaan untuk proses perhitungan availability dilakukan menggunakan Persamaan 7, sebagai bentuk representasi lain dari Persamaan 1 sebelumnya.

$$
\text { Availability }=\frac{M T B F}{M T B F+M T T R}
$$

Tabel 5.5 Hasil perhitungan MTBF, MTTR, dan Availability pada Gantry Jib Crane (GJC)

\begin{tabular}{cccc}
\hline $\begin{array}{c}\text { GJC } \\
\text { No. }\end{array}$ & MTBF & MTTR & Availability \\
\hline 02 & 93,47 & 0,67 & $98,84 \%$ \\
03 & 295,20 & 1,00 & $98,78 \%$ \\
\hline
\end{tabular}

MTBF dapat diartikan sebagai perkiraan waktu hingga komponen mengalami gangguan, sedangkan MTTR diartikan sebagai waktu yang dibutuhkan untuk memperbaiki komponen yang rusak. Dengan target availability minimal $90 \%$, dapat dikatakan bahwa semua komponen di atas memenuhi target.

\section{Analisis Keandalan (Reliability)}

Setelah parameter-parameter Weibull dari waktu antar kerusakan didapat, maka fungsi keandalan tiap-tiap komponen dapat diketahui, sehingga keandalan masing-masing komponen dapat dianalisis.

\section{Analisis Reliability GJC 02}

Berdasarkan Persamaan 5 dan Tabel 2, maka fungsi keandalan dari GJC 02 adalah 
seperti Persamaan 8 berikut :

$$
R(t)=\exp \left(-\left(\frac{t+32.86662}{77.86674}\right)^{1.06413}\right)
$$

Dimana $\mathrm{t}=$ waktu (jam)

Dari fungsi di atas, didapat grafik keandalan GJC 02 seperti terlihat pada Gambar 2 berikut ini.

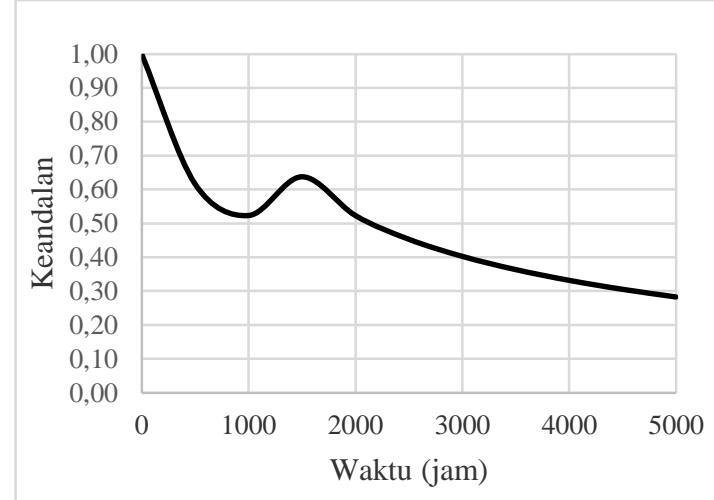

\section{Gambar 2. Grafik keandalan GJC 02 terhadap waktu}

Penentuan jadwal preventive maintenance dapat dilakukan berdasarkan model distribusi probabilistik untuk menentukan interval waktu preventive maintenance berdasarkan nilai reliability yang diinginkan (Shanaz, 2015).

Dalam menentukan interval waktu preventive maintenance, parameter lokasi, $\gamma$, harus diperhitungkan, karena parameter ini dapat dianggap sebagai waktu jaminan dimana kegagalan tidak akan terjadi. Diketahui standar keandalan minimum adalah $90 \%$. Oleh karena itu, penentuan interval waktu preventive maintenance (PM) dapat dilakukan menggunakan Persamaan 9.

$$
t_{p m}=\theta(-\ln 0.90)^{\frac{1}{\beta+\gamma}}
$$

Dari Persamaan 9, didapat waktu interval preventive maintenance yaitu 280,40 jam.

\section{Analisis Reliability GJC 03}

Berdasarkan Persamaan 5 dan Tabel 2, maka fungsi keandalan dari GJC 03 dinyatakan seperti pada Persamaan 9, dan dari fungsi tersebut didapatkan grafik keandalan pada GJC 03 seperti terlihat pada Gambar 3.

$$
R(t)=\exp \left(-\left(\frac{t+28.09714}{109.84284}\right)^{1.08390}\right)
$$

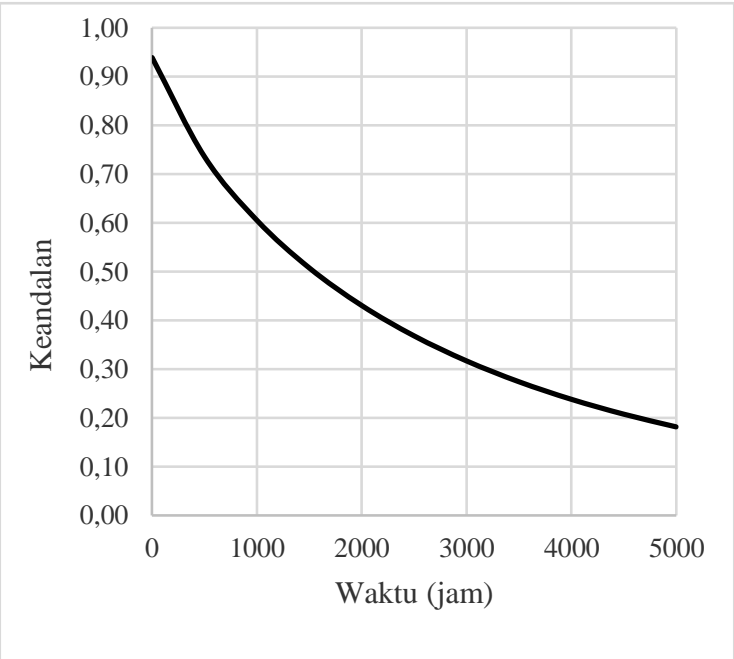

\section{Gambar 3. Grafik keandalan GJC 03 terhadap waktu}

Dengan menggunakan Persamaan 9, didapat waktu interval preventive maintenance Gantry Jib Crane 03 yaitu 295,40 jam.

\section{KESIMPULAN}

Dari hasil perhitungan availability dari alat bongkar muat Gantry Jib Crane berdasarkan data-data yang diperoleh dari history dan record data yang telah diperoleh, didapat nilai-nilai availability untuk Gantry Jib Crane 02 sebesar 98,84\% dan Gantry Jib Crane 03 sebesar 98,78\%. Perkiraan interval predictive maintenance untuk Gantry Jib Crane 02 adalah 72,84 jam dan Gantry Jib Crane 03 adalah 101,67 jam.

\section{DAFTAR PUSTAKA}

Hardianto, A., Pratikto, P., \& Yuliati, L. (2015). PERAWATAN HOIST CRANE DENGAN METODE MAINTAINABILITY DAN COSTING UNTUK MENGURANGI BREAKDOWN. Journal of Engineering and 
https://www.jemis.ub.ac.id/index.php/je mis/article/view/165

Hauptmann, S., Scherping, I., Dröse, S., Brandt, U., \& ... (2009). Mitochondrial dysfunction: an early event in Alzheimer pathology accumulates with age in AD transgenic mice. Neurobiology of .... https://www.sciencedirect.com/science/a rticle/pii/S0197458007004678

Hogan, C. E., Johnson, M. F., \& Ramesh, K. (2011). The unintended consequences of PCAOB auditing Standard Nos. 2 and 3 on the reliability of preliminary earnings releases. Journal of Accounting and .... https://www.sciencedirect.com/science/a rticle/pii/S0165410110000273

Mokashi, A. J., Wang, J., \& Vermar, A. K. (2002). A study of reliability-centred maintenance in maritime operations. Marine Policy. https://www.sciencedirect.com/science/a rticle/pii/S0308597X02000143

Oystein, J. (1948). Method of fabricating packing glands. US Patent 2,448,147. https://patents.google.com/patent/US244 8147A/en

Rosihan, R. I., \& Yuniarto, H. A. (2019). Analisis Sistem Reliability dengan Pendekatan Reliability Block Diagram. In Jurnal Teknosains. pdfs.semanticscholar.org.

https://pdfs.semanticscholar.org/3d7a/04 c864ae2dea1e70fd58d25e8e2c988e5a10. pdf

Shanaz, B., Arunachalam, G., Jayaveeera, K. N., \& ... (2012). Pharmacognostic studies of Barleria montana Dun. leaves. World Journal of https://www.cabdirect.org/cabdirect/abst ract $/ 20123304483$

Stapelberg, R. F. (2009). Handbook of reliability, availability, maintainability and safety in engineering design. books.google.com.

https://books.google.com/books?hl=en \& $\mathrm{lr}=\& \mathrm{id}=\mathrm{b} 4$ UudC1EIIoC\&oi=fnd \&pg $=\mathrm{P}$ A $2 \& d q=$ stapelberg \&ots $=$ tCncXyf5ZH\& sig=DM-6DL6pV7fawjLayqq_1pSjU8

Tsarouhas, P. (2007). Implementation of total productive maintenance in food industry: a case study. Journal of Quality in Maintenance Engineering. https://doi.org/10.1108/13552510710735 087

Wu, J., Rosenbaum, E., Begum, S., \& ... (2007). Distribution of BRAF T1799A (V600E) mutations across various types of benign nevi: implications for melanocytic tumorigenesis. The American journal of .... https://journals.lww.com/amjdermatopat hology/fulltext/2007/12000/distribution_ of_braf_t1799a_v600e_mutations.2.asp $\mathrm{X}$ 